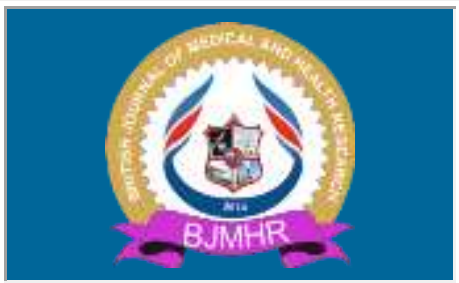

\title{
BJMHR
}

British Journal of Medical and Health Research

Journal home page: www.bjmhr.com

\section{Describing Professionalism Levels of Health Managers}

Fatih Aksu', Birkan Tapan ${ }^{2 *}$

1.Altınbas University, Vocational High School, Department Of Management and

Organization, Istanbul, Turkey.

2.Demiroglu Bilim University, Vocational High School of Health Services, Healthcare Organizations Management, Istanbul, Turkey.

\section{ABSTRACT}

This research was conducted to determine the level of professionalism of health care managers. Therefore, the personal and professional differences affecting the levels of professionalism of individuals working in private or public hospitals and working as managers in different fields were investigated and the results obtained were compiled. In the study, 123 individuals from the universe of 218 people were reached and the ones who were reached were asked to complete Swailes questionnaire (2003). Results show that the as the level of education increases, levels of professionalism of also increases. According to our results, choosing the occupation consciously has a positive effect on professionalism level. Also, the time of managerial duty was also founded as a factor contributing to the professionalism level. Lastly, the results showed that the level of professionalism is higher among people who positioned as 'different levels of management' than those who have other positions. In the light of these results, it is recommended to increase the education levels of the people who work as managers, to help people choose the profession consciously and to provide support for increasing the level of professionalism in all levels, not only in the time of the managerial duty. In addition, it is important to encourage the activities among people who work in different positions in health institutions to increase their professional professionalism skills equally.

Keywords: Health, Management, Professionalism, Occupation 


\section{INTRODUCTION}

A person is considered as professional if he/she has emerged due to social requirements, is open to changes and development, has a market value, has been educated for the requirements of the job that has unique rules and laws, can fulfill the requirements of the current job, has mastered the characteristics of the job and has proven it to the people around.

The concept of professionalism has evolved by the time. All employees, not some occupational groups, individuals and organizational structures should accept and adapt the idea and attitude of professionalism. This concept is also of great importance in the formation and development of occupational standards. ${ }^{1}$

The urgent and irreversible service provided in health institutions, the difference in terminology within the scope of service, the unpredictable and flexible demand, the necessity of working together with different occupational groups in the field of education and so on requires absolute professionalism. The complex structure that is present in health institutions makes it different from other organizations in terms of the managing the health institutions. Therefore, health institutions should have the necessary number of personnel and quality workforce with this awareness.

Health centers, home care centers, maternal and child health centers or private practices have a very complex organizational structure. Hospitals need to be well managed and the management process is the most complex compared to other health institutions, as the existing staff is composed of professionals and the services they offer are complicated. ${ }^{2}$

Hospitals are defined as institutions that provide health services categorized as surveillance, diagnosis, improvement and rehabilitation and in which patients are treated according to their diseases within the specified period of time. ${ }^{3}$

Today, hospitals that provide services by benefiting from modern methods and technological developments need health managers to continue without sacrificing the quality of the service they provide. $^{2}$ In health sector, where billions of dollars are invested, the people who are assigned as managers in health institutions must be professionals to meet the demands of the era.

In the light of these explanations, the aim of this study was to determine the position of director of public and private sector executives involved in the levels of professionalism in Turkey, described as giving support for improving the level of professionalism of these individuals.

\section{METHODOLOGY AND DESIGN:}

The universe of this research consists of 210 managers who work in different levels of management in private and public institutions and organizations within the provincial border 
of Istanbul. The aim of the study was to reach the whole universe instead of selecting a sample. 123 of the surveys received feedback, thus reaching $58.57 \%$ of the universe.

In order to achieve the aim of the research, questionnaire technique was used. The aim of the questionnaire was to determine the level of professionalism of the health institution managers. The Professional Scale, which was developed by Swailes ${ }^{4}$ and adapted to Turkish by Seçer ${ }^{5}$, was divided into three parts. The first part consisted of questions about the demographic information of the participants. The second part had questions about the professional knowledge of the participants. The last section included questions to determine the level of professionalism of the participants. There are a total of 21 questions in the scale which are used to determine the level of professionalism; these questions were grouped into 5 sub-dimensions. The sub-dimensions were determined as occupational ideology, occupational identity, selfcontrol of the profession, autonomy and professional identification. The first of the subdimensions, 'professional identification', is related to the internalization of the understanding supporting the identity of the profession and the behaviors required by the person.

One-way ANOVA was used to determine the differences in professionalism levels between age groups, educational backgrounds, managerial periods and staff titles. Independent Group $\mathrm{T}$ Test was used to determine whether the professionalism level showed a significant difference over the gender groups, the groups formed by the individuals' membership of the association, and the groups formed by whether the individuals had chosen their professions consciously. In order to determine the strength and direction of the relationships, Spearman Correlation Analysis was used in the groups with significant differences. In order to determine the differences between the groups, $\mathrm{p}<0.05$ was taken as the basis. Data were analyzed through SPSS package program.

\section{RESULTS AND DİSCUSSIOON}

The findings of the personal and professional characteristics of the managers who make up the first part of the research are given in Table-1.

One way Anova test was used to compare the differences between the educational and professionalism levels of health care administrators which revealed a statistically significant difference $(f=6.826 ; p=0.000)$ (Table 2).

Table 1: Results of personal and professional characteristics of managers

\begin{tabular}{lcc}
\hline Gender & $\mathrm{n}$ & $\%$ \\
\hline Male & 52 & 42.2 \\
Female & 71 & 57.8 \\
Age & & \\
$20-28$ & 10 & 8.1 \\
$29-37$ & 34 & 27.6 \\
$38-46$ & 47 & 38.2 \\
$47-55$ & 26 & 21.1 \\
\hline
\end{tabular}




\begin{tabular}{lcc}
\hline Over 55 & 6 & 4.9 \\
Education & & \\
High school & 15 & 12.2 \\
Undergraduate & 33 & 26.8 \\
Master's & 65 & 52.8 \\
Doctorate & 10 & 8.1 \\
Working Time as Administrator & & \\
1-5 & 37 & 30.1 \\
6-11 & 33 & 26.8 \\
12-17 & 16 & 13.0 \\
18-23 & 29 & 23.6 \\
Over 23 & 8 & 6.5 \\
Membership Status & & \\
Yes & 56 & 45.5 \\
No & 67 & 54.5 \\
Conscious Choice & & \\
Yes & 66 & 53.7 \\
No & 57 & 46.3 \\
Staff Titles & & \\
Hospital Manager & 6 & 4.9 \\
Chief Manager & 7 & 5.7 \\
Night Manager (sentry) & 9 & 7.3 \\
Assistant Hospital Director & 7 & 5.7 \\
Executive at Different Levels & 94 & 76.4 \\
\hline & &
\end{tabular}

Table 2. The relationship between education levels and professionalism levels of health institution managers

\begin{tabular}{llllll}
\hline & $\begin{array}{l}\text { Sum of } \\
\text { Squares }\end{array}$ & $\begin{array}{l}\text { Degree of } \\
\text { Freedom }\end{array}$ & $\begin{array}{l}\text { Average } \\
\text { Squares }\end{array}$ & F & Significance \\
\hline Between groups & 1120.476 & 3 & 373.492 & 6.826 & 0.000 \\
Intra-groups & 6511.540 & 119 & 54.719 & & \\
Total & 7632.016 & 122 & & & \\
\hline
\end{tabular}

Spearman Correlation Analysis was used to determine the relationship between education levels and professionalism levels of health institutions managers, and we found a weak and positive correlation $(\mathrm{r}=0.287 ; \mathrm{p}=0.000)($ Table 3$)$.

Table 3. Correlation analysis of the relationship between education levels and professionalism levels of health institution administrators

\begin{tabular}{llll}
\hline & & Total Point & Education \\
\hline Total Point & Pearson Correlation & 1 & $0.287^{* *}$ \\
& Significance (two-sided) & & 0.001 \\
& $\mathrm{~N}$ & 123 & 123 \\
Education & Pearson Correlation & $0.287^{* *}$ & 1 \\
& Significance (two-sided) & 0.001 & \\
& $\mathrm{~N}$ & 123 & 123 \\
$* *$ Correlation is significant at 0.01 (bidirectional). \\
\hline
\end{tabular}


Spearman Correlation Analysis was conducted to determine the relationship between the managerial periods and professionalism levels of health care managers and we showed that there was a weak and positive relationship between them $(r=0.269 ; p=0.011)$ (Table 4).

Table 4. Correlation analysis of the relationship between the duration of management and professionalism levels of health institution administrators

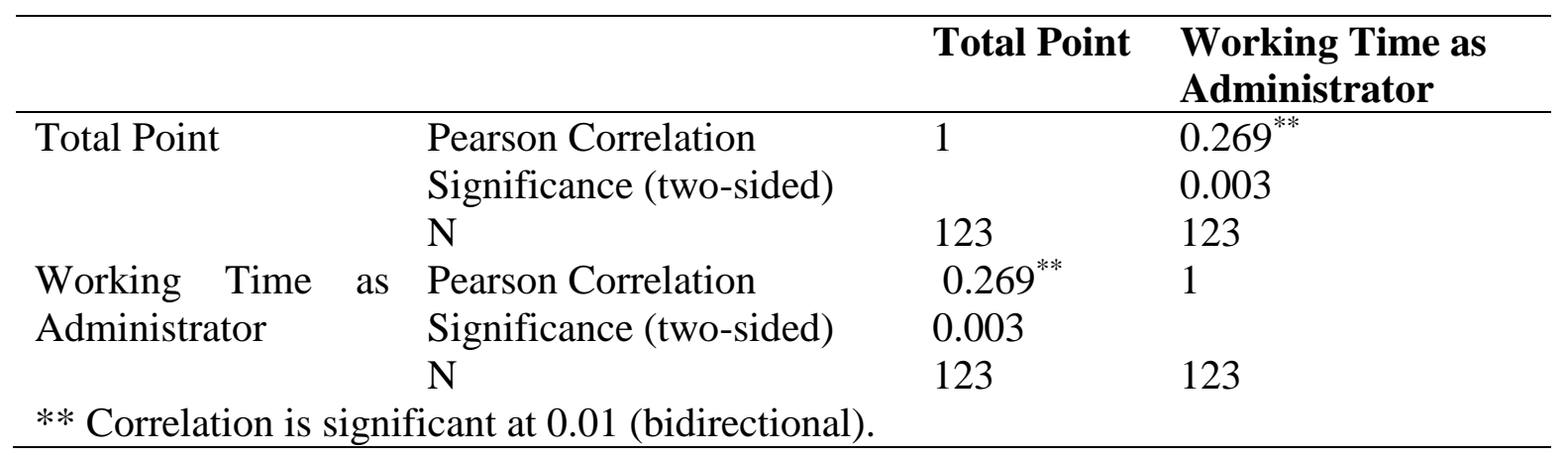

Independent Group T test was used to compare the differences between the status of conscious and non-selective occupations of health institutions managers and their professionalism levels. Accroding to our results, we found a statistically significant difference between these parameters ( $\mathrm{f}=4.370 ; \mathrm{p}=0.039)$ (Table 5).

Table 5. Relationship between membership status and professionalism levels of health institution administrators

\begin{tabular}{|c|c|c|c|c|c|c|c|c|c|}
\hline \multirow[b]{2}{*}{$\begin{array}{l}\text { Total } \\
\text { Point }\end{array}$} & \multicolumn{2}{|c|}{ Levene Variance } & \multicolumn{7}{|l|}{ T test } \\
\hline & $\mathbf{F}$ & $\begin{array}{l}\text { Significan } \\
\text { ce }\end{array}$ & $\mathbf{t}$ & df & $\begin{array}{l}\text { Significa } \\
\text { nce (two- } \\
\text { way) }\end{array}$ & $\begin{array}{l}\text { Average } \\
\text { Differen } \\
\text { ces }\end{array}$ & $\begin{array}{l}\text { Standart } \\
\text { Deviation } \\
\text { Differences }\end{array}$ & $\begin{array}{l}\mathrm{P}<0.0 \\
5\end{array}$ & $p>0.05$ \\
\hline default & $\begin{array}{l}1.33 \\
7\end{array}$ & 0.25 & 2.273 & 114 & 0.025 & 3.163 & 1.392 & 0.406 & 5.920 \\
\hline $\begin{array}{l}\text { non- } \\
\text { default }\end{array}$ & & & 2.259 & 107.591 & 0.026 & 3.163 & 1.400 & 0.387 & 5.938 \\
\hline
\end{tabular}

One way Anova test was used to compare the differences between the staff titles and professionalism levels of the health institutions managers (Table 6). A statistically significant difference was found according to the evaluation results ( $f=3.627 ; p=0.008$ ).

Table 6. The relationship between the professionals of health managers title and professional levels

\begin{tabular}{llllll|}
\hline & Sum of Squares & $\begin{array}{l}\text { Degree of } \\
\text { Freedom }\end{array}$ & $\begin{array}{l}\text { Average } \\
\text { Squares }\end{array}$ & F & Significance \\
\hline Between groups & 835.569 & 4 & 208.892 & 3.627 & 0.008 \\
Intra-groups & 6796.448 & 118 & 57.597 & & \\
Total & 7632.016 & 122 & & & \\
\hline
\end{tabular}

According to the results obtained, it was found that the level of professionalism of the title holders working at different levels in health institutions was higher than the other title holders. It was concluded that the managers with the lowest professionalism score were night (on duty) managers. 
As a result of Spearman Correlation Analysis (Table 7), which was made on the determination of the relationship between health care staff managers and professional titles, a weak and positive relationship was found $(\mathrm{r}=0.272 ; \mathrm{p}=0.008)$.

Table 7. Correlation analysis of the relationship between staff titles and professionalism levels of health institution administrators

\begin{tabular}{llll}
\hline \multirow{3}{*}{ Title } & Pearson Correlation & Title & Total Point \\
& Significance (two-sided) & & $0.272^{* *}$ \\
\multirow{5}{*}{ Total Point } & N & 123 & 0.002 \\
& Pearson Correlation & $0.272^{* *}$ & 123 \\
& Significance (two-sided) & 0.002 & \\
& N & 123 & 123 \\
$* *$ Correlation & is significant at 0.01 (bidirectional). \\
\hline
\end{tabular}

\section{DISCUSSION:}

In the light of these findings, firstly, we found that age difference had no effect on the professional level of individuals. In the literature, there is a positive linear relationship between professional satisfaction (job satisfaction) and professional level. ${ }^{6}$ At the same time, it has been proven that the occupational satisfaction increases as the person grows old ${ }^{7}$. In the light of the information available in the literature; age factor was expected to have an effect on the level of professionalism, but the results did not meet this expectation. On the other hand, these findings are consistent with the results of Inel and Akbulut study which has examined the levels of professionalism of health care managers. ${ }^{8}$ According to the data of this study, there was no significant difference between age and levels of professionalism.

The effect of gender differences on professionalism level was not significant. The study of Inel and Akbulut showed that, similar to age, the gender factor had no effect on the level of professionalism. ${ }^{8}$ In support of Inel and Akbulut's study, Lewis and Carlan found that there was no significant relationship between gender and professionalism. ${ }^{9}$ In the light of these findings, it is possible to state that there is no difference between gender groups and professionalism levels.

In our study, a significant difference was found between the levels of professionalism among the educational status groups which were hypothesized. The results showed that the higher the level of education, the higher the level of professionalism was. In the literature, there are many studies supporting our results. Grover stated that the increase in the level of education was directly related to the level of professionalism conducted among nurses and that the nurses with higher level of education behaved more professionally. ${ }^{10}$ Similarly, in the study conducted by Kantek, Kaya and Gezer, it was found that the education of the person directly affected the professional level of workers. ${ }^{11}$ The results related to education coincide with the descriptive scope of professionalism and the characteristics of professional professionalism. Considering 
that one of the first conditions of professionalization in any profession is theoretical and practical training received in that field, it is possible that the increase in the level of education of individuals will increase their professionalism levels. Therefore, the findings obtained in the study support the relevant literature.

A significant difference was found between the management periods and professionalism levels of the managers. Similarly, in a study conducted in the United States in which nurses were selected as occupational groups and determining the level of professionalism, it was found that the nurses with longer managerial periods obtained higher scores. ${ }^{12}$ In the literature, there are similar studies which have not found any significant difference between the time spent by physicians in the profession, duration of service of the police and working hours and professionalism levels. ${ }^{9,}, 13$

Within the scope of the study, it was found that there was no significant difference between the status of being a member of professional association or community and the level of professionalism. Therefore, it can be concluded that membership to occupational groups is not a factor affecting the professionalism level of health institutions managers. In a study involving engineers, it was also stated that membership in professional chambers did not affect the level of professionalism. ${ }^{14}$

In a study conducted on the level of professionalism of nurses, it was found that nurses who were members of associations or professional communities had higher total professional scores than non-members, and in a study conducted on journalists, it was found that total professionalism scores of member journalists of professional associations were higher. ${ }^{12,15}$ A significant difference was found whether the deliberate choice of profession had an impact on the level of professionalism. The data obtained are supported by many studies in the literature. Inel and Akbulut found that the level of professionalism of those who consciously chose their profession was much higher than those who chose it unconsciously. ${ }^{8}$ Similarly, in a study conducted by Kim-Godwin et al. among Korean nurses, it was found that the level of professionalism of nurses who chose their profession consciously was higher than their colleagues who chose the profession unconsciously. ${ }^{16}$

The last hypothesis in the study revealed was a significant difference between the professionalism levels of the cadre groups. According to the findings, differences between the dimensions of the staff increase or decrease the level of professionalism. When analyzed in detail, the 'managers at different levels' group, which is one of the mentioned title holders, was determined to have the highest average score in professionalism level. Similarly, the study conducted by Emre among journalists, in which staff titles differ in professionalism level, supports the findings. ${ }^{15}$ 
In this study, hypotheses were tested to determine the level of professionalism of health care providers. As a result of the study, we determined that the education levels, conscious choices of professions, term of managerial duties and the titles of individuals who are working in health institutions play a role in increasing their professionalism levels.

\section{CONCLUSION:}

Since there is a significant difference between the managerial periods and professionalization, in order for the persons assigned to the managerial position to perform their duties properly; granting sufficient time, getting used to the task and supporting the follow up of the field in the field can be presented as another suggestion. Lastly, considering that the professionalization in health care institutions in our country is still under process, it is necessary to continue the studies covering the professionalism process in this field and the characteristics of professionals. Nowadays, the increasing demand for health services in line with the increase in the human population has made it necessary for the professionalization of the employees, who are in the executive position of the institutions providing this service, the first step of professionalization.

In this context, choosing an occupation deliberately will help it become a profession. For this reason, the number of institutions or associations providing education in health should be increased and studies should be carried out in order to ensure that the occupations to be managed in health institutions are known and recognized. Increasing the opportunities of health care personnel for postgraduate education can be seen as one of the suggestions that will increase the professionalism in this field. Uncertainties of the professional fields and deficiencies in the field of legislation, ensuring the legal recognition of the profession, clearly drawing the boundaries of the duties and powers will enable them to motivate them to increase their professionalism in order to raise their titles as this will relieve hierarchically low level managers.

\section{REFERENCES}

1. Gökçora IH. Toplumsal yaşamımızda ve Türk bilim-dünyasında "profesyonel ve profesyonellik" kavramlarına değin. Bilgi Dünyas1; 2005,6:237-250.

2. Kaptanoğlu AY. Sağlık Yönetimi. Istanbul: Beşir Kitabevi; 2011,584 p.

3. World Health Organization. Selection of indicators for hospital performance measurement. Copenhagen: WHO; 2004.

4. Swailes S. Professionalism: Evolution and measurement. Serv Ind; J 2003,23:130-149.

5. Seçer Ş. Mesleki yaşam modelinin oluşturulması ve mesleki analizlerde kullanımı. Sosyal Bilimler; 2009,7:35-56. 
6. Boyt TE, Lusch RF, Naylor G. The role of professionalism in determining job satisfaction in professional services: A study of marketing researchers. JSR;2001, 3:321-330.

7. Baş $T$, Ardıç $K$. The impact of age on the job satisfaction of Turkish academicians. GÜIII BF Dergisi; 2002,2,89-102.

8. Inel S, Akbulut Y. Sağlık kurumları yöneticilerinin profesyonellik düzeyinin belirlenmesi. Hacettepe Sağl1k İdaresi Dergisi; 2017,20:109-124.

9. Lewis JA, Carlan PE. Professionalism in policing: assessing the professionalization movement. Professional Issues In Criminal Justice; 2009,4:39-57.

10. Grover SL. The effect of increasing education on individual professional behavior and commitment. J Vocat Behav; 1992,40:1-13.

11. Kantek F, Kaya A, Gezer N. The effects of nursing education on professional values: A longitudinal study. Nurse Educ Today; 2017,58:43-46.

12. Wynd CA. Current Factors Contributing to professionalism in nursing. J Prof Nurs; 2003,19:251-261.

13. Wimmer PL. Professionalism among medical practitioners: a case study of rural physicians. Faculty of the Virginia Polytechnic Institute and State University, Degree of Master Thesis, Virginia, USA; 2007.

14. Bilginoğlu B. Professionalization level of engineering and validity of $\mathrm{Y}$ theory assumptions for engineers, $\mathrm{PhD}$ Thesis, Ankara; 2013.

15. Emre H. Türkiye'deki gazetecilerde profesyonellik düzeyinin belirlenmesine yönelik bir alan araştırması. Unpublished Master's Thesis, Hacettepe Üniversitesi, Ankara; 2009.

16. Kim-Godwin YS, Baek HC, Wynd CA. Factors influencing professionalism in nursing among Korean American registered nurses. J Prof Nurs; 2010,26:242-249.

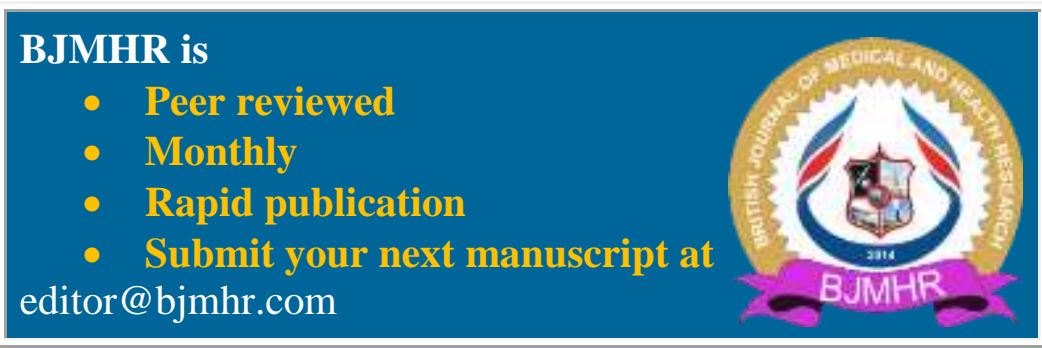

